\title{
The Behavior of High Strength Self-Compacting Reinforced Concrete Corbels Strengthened with NSM Steel Bars
}

\author{
Qasim M. Shakir", Hayder H. H. Kamonna* \\ ${ }^{\#}$ Civil Department, University of Kufa, Najaf, 00964, Iraq \\ E-mail: qasimm.alabbasi@uokufa.edu.iq; hayder.kammona@uokufa.edu.iq
}

\begin{abstract}
An experimental investigation conducted with studying the behavior high strength self-compacting reinforced concrete corbels strengthened with NSM steel bars. The experimental work involved testing ten corbel specimens. They are categorized into two groups with two values of shear span/depth ratio (a/d). Each group consists of five specimens, one considered as a control; others were strengthened with four different configurations of NSM steel bars. The load-deflection curves were traced, cracking and ultimate loads were recorded, crack width was measured and crack propagation up to failure was trucked. This research found that strengthening RC corbel with NSM steel bar system improved the failure load significantly by $57 \%$ and $41 \%$ for a/d of 0.85 and 1.25 respectively. The strengthening system named as "Upside down V-shaped" is more efficient for small values of a/d (a/d $<1)$. The horizontal bars configuration is more convenient for large $\mathbf{a} / \mathbf{d}$ values $(\mathbf{a} / \mathbf{d}>1)$; with $\mathbf{a} / \mathbf{d}$ greater than one, the general mode of failure is of Bond type. Also, it is found that the strengthening of specimens results in some elimination in ductility with a value depending on the strengthening configuration.
\end{abstract}

Keywords — high strength; self-compacting; NSM steel bar; strengthening; corbels.

\section{INTRODUCTION}

Corbels are defined as "short cantilevers that tend to act as simple trusses or deep beams, rather than beams" [ACI318M-14]. They can be designed using Shear Friction Method for a/d up to unity and adopting Strut and Tie Model (STM) for a/d values less than two [ACI-318M-14]. They are commonly used in precast concrete industry. The primary role of corbels is to transfer heavy concentrated loads of precast beams and cranes to the supporting members (columns or walls). Such elements are cast monolithically with their supports. They are designed to resist high shear forces accompanied with relatively small bending moments. These elements host a zone of discontinuity and stress concentration. So, the assumption that sections remain plane after deformation is not valid yet. [1].

The modes of failure for corbels are characterized to be as "shearing along the interface between the column and the corbel, yielding of the tension tie, crushing or splitting of the compression strut, localized bearing or shearing failure under the loading plate" [ACI-318M-14]. Such modes of failure are shown in Fig. 1 [2].

Many experimental and theoretical studies were published to investigate the performance of reinforced concrete corbels, others concerned with the different strengthening techniques of such elements. In 1976, the behavior of reinforced concrete corbels under vertical and horizontal loads had been tested [3]. Aziz investigated the influence of crushed stone on the shear strength of reinforced concrete corbels [4]. The effect of longitudinal and transverse steel reinforcement, hooked steel fibers on the behavior of reinforced concrete corbel were studied [5]. They also studied retrofitting of these structural elements by the external wrapping of CFRP sheet. An experimental study of the behavior of high strength reinforced concrete corbels with and without fibers was studied [6]. In 2015, self-compacting of high and normal strength concrete corbels subjected to static and repeated loads were investigated [7]. Iliyas et al. examined concrete corbels in 2016 [8].

Corbels need to be strengthened or upgraded in some cases such as luck in design, excessive loading, and deterioration due to severe climate conditions. The most methods that have been suggested to improve the strength of corbels is the jacketing by either steel plate or CFRP sheets. In Steel plate jacketing method, holes need to be drilled. This may affect the corbel strength seriously. Whereas in CFRP jacketing, sheets may be delaminated. To overcome such problems, the near surface mounted (NSM) carbon bar technique has been recently proposed in several studies.

Yang et al. investigated the behavior of high-strength concrete experimentally (HSC) corbels with post-installed 
T-headed bars as the central reinforcements [9]. Ahmad et al. investigated the shear response enhancement of HSC corbels strengthened with CFRP sheets [10]. Mohammed et al. studied the strengthening of RC corbels by precast ferrocement sheets [11]. Ivanova and Assih reported two experimental studies, one related with strengthening of reinforced concrete corbels by carbon fiber fabrics, other dealt with tracking the path of the cracks under static and dynamic loading [12]. Assih et al. 2015 studied the strengthening of damaged RC corbels by carbon fiber fabrics [13]. Yujie presented an experimental and analytical study of RC corbels strengthened with two systems, namely, CFRP sheets and (NSM) CFRP rods [14]. Urban and Krawczyk studied the influence of using post installed threaded rods as additional reinforcement on the shear behavior of reinforced concrete corbels [15].

From this brief literature review, it is evident that no study has been published about the strengthening of RC corbels, in general, by NSM steel bars. The present work adopts steel bar rather than the presently used CFRP rods in NSM strengthening technique of self-compacted high strength RC corbels, due to the high cost of CFRP bars and weakness in bending and compression. In contrast, the low price of steel bars, the good bendability and compression resistance. Several schemes of NSM steel bars have been suggested to upgrade the performance of reinforced concrete corbels.

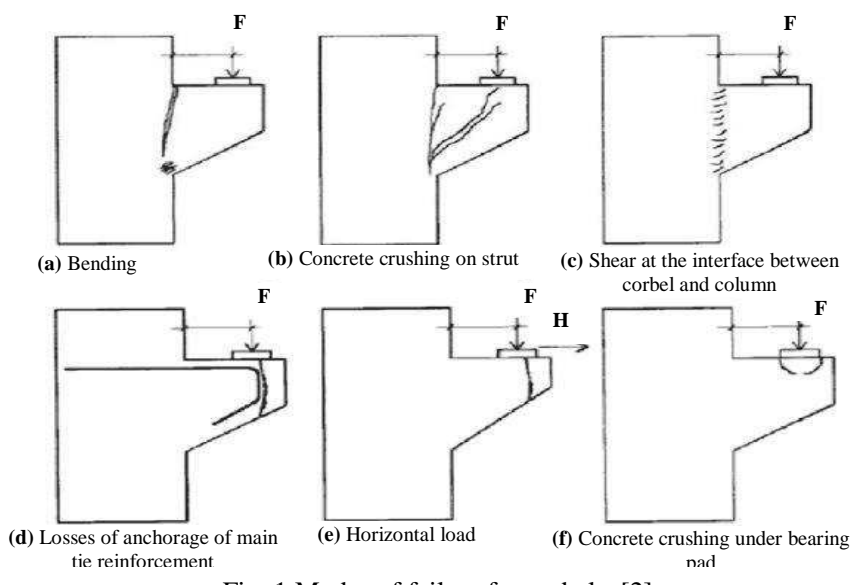

Fig. 1 Modes of failure for corbels [2]

\section{MATERIALS AND METHOD}

\section{A. Materials}

The concrete mix composed of Ordinary Portland Cement (Type I) manufactured by KAR Company, natural gravel of max size of $19 \mathrm{~mm}$ as coarse aggregate, natural sand imparted from Al-Najaf zone, limestone powder as the filler and GILENIUM ®54 as superplasticizer. Clean tap water was used.

\section{B. Method of Experimental Work}

Ten high strength self-compacting corbels (HSSCC) with details shown in Fig. 2 have been tested experimentally in this work. They are categorized into two groups based on (effective span/depth) ratio. For each group, one specimen is considered as a control specimen whereas the four others are strengthened with the strengthening configurations shown in Fig. 3. Material properties of concrete, steel bar, and epoxy are detailed in Table 1. A list of designation for the tested specimens is given in Table 2.

When the specimens gained the required strength (28 days), grooves have been introduced within the concrete surface with dimensions of $(15 \mathrm{~mm} \times 15 \mathrm{~mm})$. A layer of epoxy has been laid. A steel bar is installed. Then, the groove is filled with epoxy. The test is done two weeks later to allow the epoxy to gain the required strength.

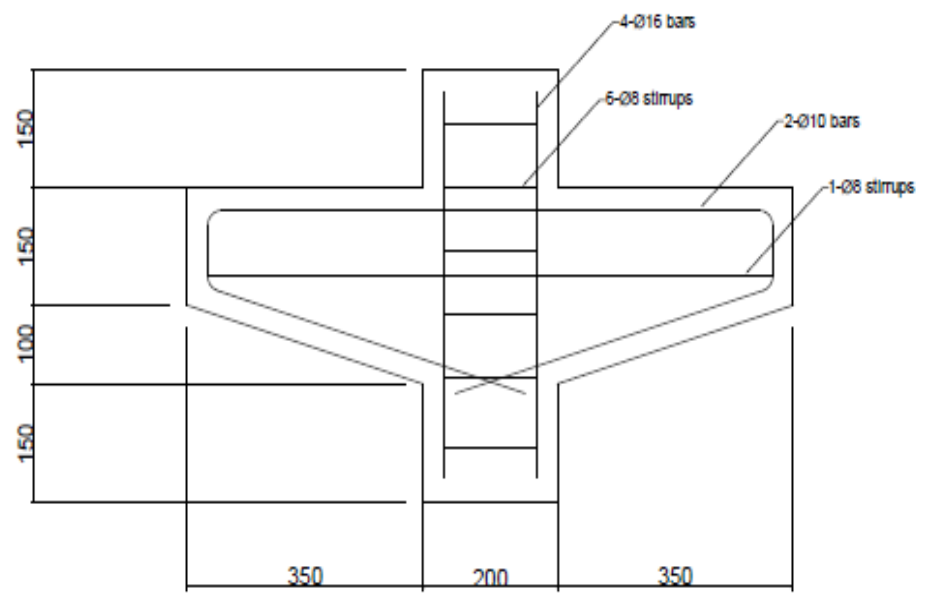

Fig. 2 Corbel dimensions and reinforcement details

TABLE I

MATERIAl PROPERTIES OF CONCRETE, STEEL BAR AND EPOXY

\begin{tabular}{|c|c|c|c|c|}
\hline \multicolumn{2}{|c|}{ Material } & $\mathbf{f}_{c}(\mathbf{M P a})$ & $\begin{array}{c}\mathbf{f}_{\mathbf{t}} \\
(\mathbf{M P a})^{*}\end{array}$ & $\begin{array}{c}\mathbf{f}_{\mathbf{u}} \\
(\mathbf{M P a})\end{array}$ \\
\hline \multicolumn{2}{|c|}{ Concrete } & 78 & 3.7 & - \\
\hline \multirow{4}{*}{ 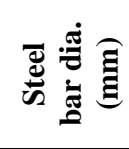 } & 8 & 510 & - & 620 \\
\hline & 10 & 530 & - & 635 \\
\hline & $10 * *$ & 525 & - & 640 \\
\hline & 16 & 520 & - & 660 \\
\hline \multicolumn{2}{|c|}{$\begin{array}{c}\text { Epoxy type } \\
\text { Sikadur®30 }\end{array}$} & 85 & 25 & - \\
\hline \multicolumn{5}{|c|}{$*=\mathrm{f}_{\mathrm{y}}$ for steel $\quad * *=$ steel bar of strengthening } \\
\hline
\end{tabular}

TABLE II

DESIGNATION FOR THE TESTED SPECIMENS

\begin{tabular}{|c|c|c|c|}
\hline Group No. & $\mathbf{a} / \mathbf{d}$ & $\begin{array}{l}\text { Specimen } \\
\text { Designation }\end{array}$ & Strengthening method \\
\hline \multirow{5}{*}{ 일 } & 0.85 & $\mathrm{CC} 1$ & control \\
\hline & 0.85 & CS11 & horizontal bars \\
\hline & 0.85 & CS12 & Semi triangle \\
\hline & 0.85 & CS13 & V-shaped \\
\hline & 0.85 & CS14 & Upside down V-shaped \\
\hline \multirow{5}{*}{$\stackrel{0}{0}$} & 1.25 & $\mathrm{CC} 2$ & control \\
\hline & 1.25 & CS21 & horizontal bars \\
\hline & 1.25 & CS22 & Semi triangle \\
\hline & 1.25 & CS23 & V-shaped \\
\hline & 1.25 & CS24 & Upside down V-shaped \\
\hline
\end{tabular}




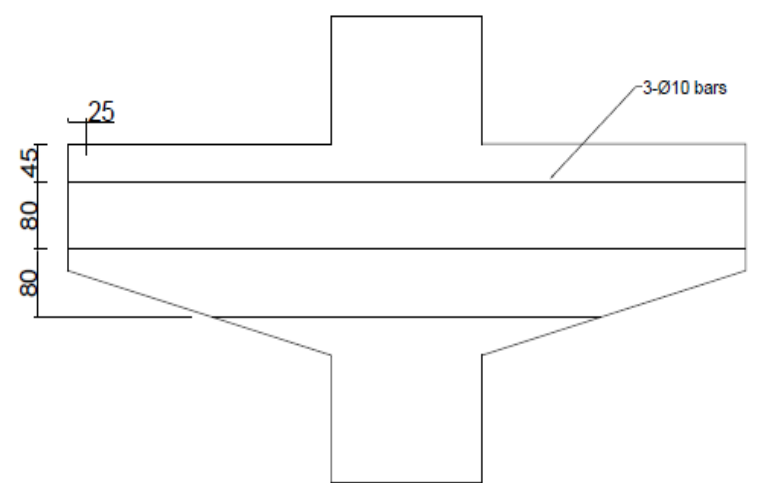

(a) $\mathrm{CS} 11$ or $\mathrm{CS} 21$

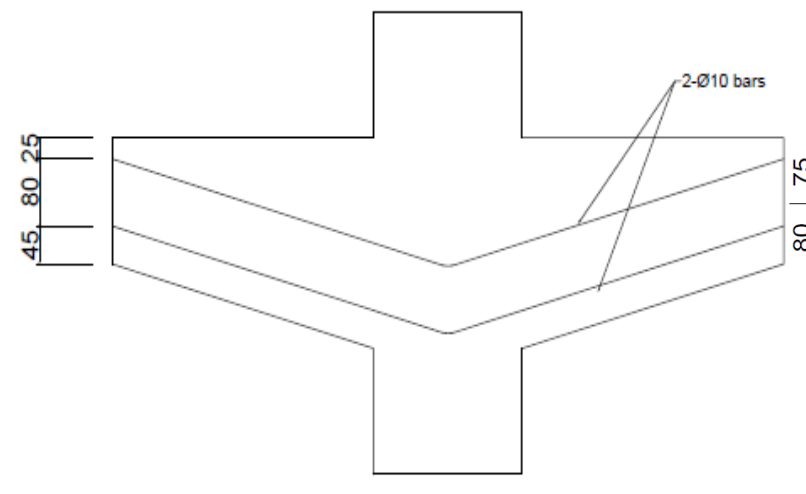

(c) $\mathrm{CS} 13$ or $\mathrm{CS} 23$

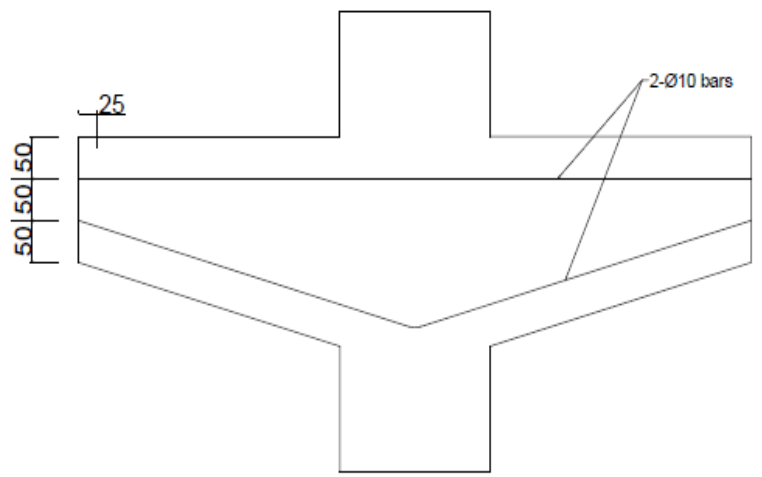

(b) $\mathrm{CS} 12$ or $\mathrm{CS} 22$

Fig. 3 Configurations of strengthening

\section{RESULTS AND DISCUSSION}

\section{A. Load Deflection Curves}

The load-deflection curves for tested corbel are shown in Fig. 4. It is clear that a/d has a negligible effect within the initial stages of loading. However, this effect becomes more obvious with the progress of loading. It can also be concluded that the ductility increased with increasing $\mathrm{a} / \mathrm{d}$ value (from $0.85-1.25$ ).

Fig. 5 depicted the effect of strengthening scheme on the response of the tested corbels. It can be simply concluded that the specimens (CS14 and CS24) despite having different $\mathrm{a} / \mathrm{d}$ values, yielded the most rigid behavior of the different configurations for the same group. In general, strengthening results in the elimination of ductility in value depending on the strengthening scheme.

\section{B. Crack Patterns}

Fig. 6 shows the distribution of cracks at load failure. It can be seen that a/d value is a dominant factor in determining the intensity of cracks, i.e., some crack number of cracks is recorded for a smaller value of a/d. Also, it can be recognized that localization of crack near the column for unstrengthened specimens compared with spread cracks for strengthened specimens.

\section{Ultimate Load and Mode of Failure}

The cracking load, ultimate load and mode of failure for each of the tested specimens are listed in Table 3.
Concerning crack and ultimate loads, it is found that $\mathrm{a} / \mathrm{d}$ has considerable influence on unstrengthened specimens. This effect is reduced with adopting strengthening. i.e., for the control corbels, adopting a/d of 1.25 rather than 0.85 results in a reduction in the crack and ultimate loads of $20 \%$ and $30 \%$ respectively. Whereas for strengthened specimens, the effect of a/d is ranged by (9-16) \% and (23-38)\% respectively.

It can be seen that the best enhancement in the ultimate load for the strengthened specimens is $57 \%$ and $41 \%$ for a/d of 0.85 and 1.25 respectively. Also, the results reveal that the "Upside down V-shaped" scheme is more efficient for small $\mathrm{a} / \mathrm{d}$ values $(\mathrm{a} / \mathrm{d}<1)$. Whereas, the configuration of installing horizontal bars is more convenient for large $\mathrm{a} / \mathrm{d}$ values $(\mathrm{a} / \mathrm{d}>1)$

Regarding the mode of failure, a gradual transition from direct shear to diagonal shear for unstrengthened specimens when adopting higher values of $\mathrm{a} / \mathrm{d}$. For strengthened specimens with a/d of 0.85 different failure modes can be seen depending on the configuration of strengthening. While, the general mode of failure for the strengthened specimens with $\mathrm{a} / \mathrm{d}$ of 1.25 , it is found to be a bond failure.

\section{Crack Width}

Fig. 7 shows the effect of a/d on the rate of crack width development for the tested specimens. In general, the results reveal that increasing $\mathrm{a} / \mathrm{d}$ results in more rapid crack development for a specific load. 

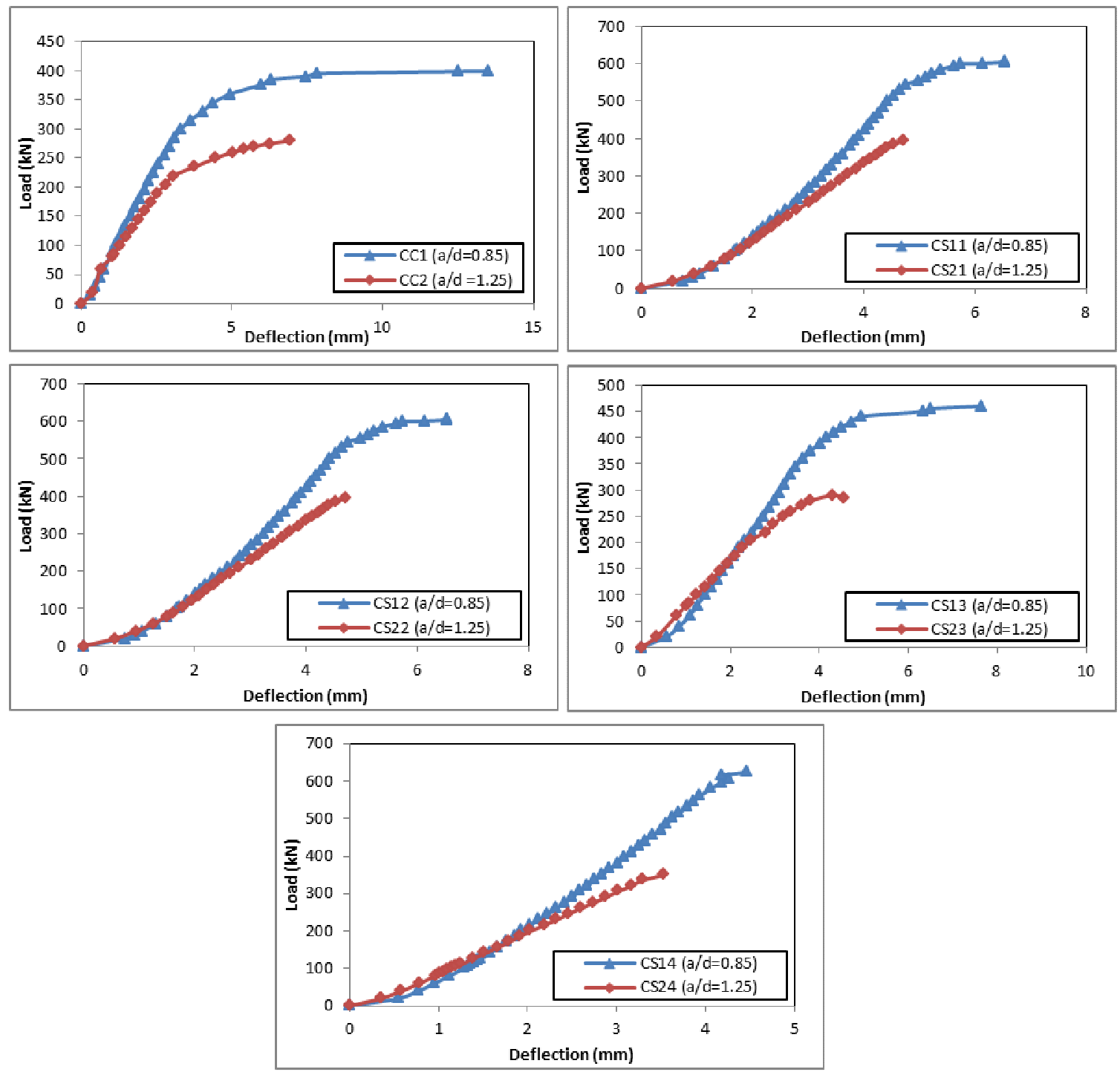

Fig. 4 Load deflection curves of tested corbels

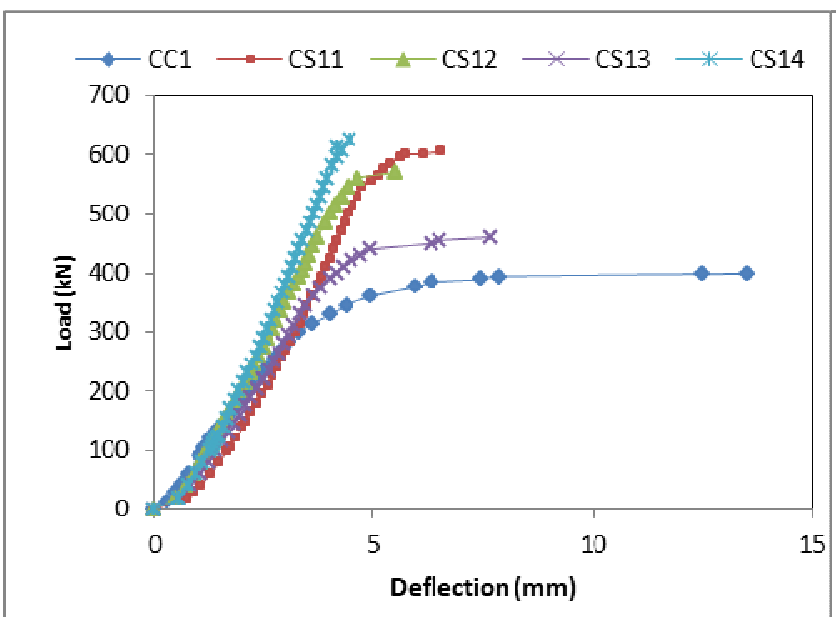

(a) effective depth/ $\operatorname{span}=0.85$

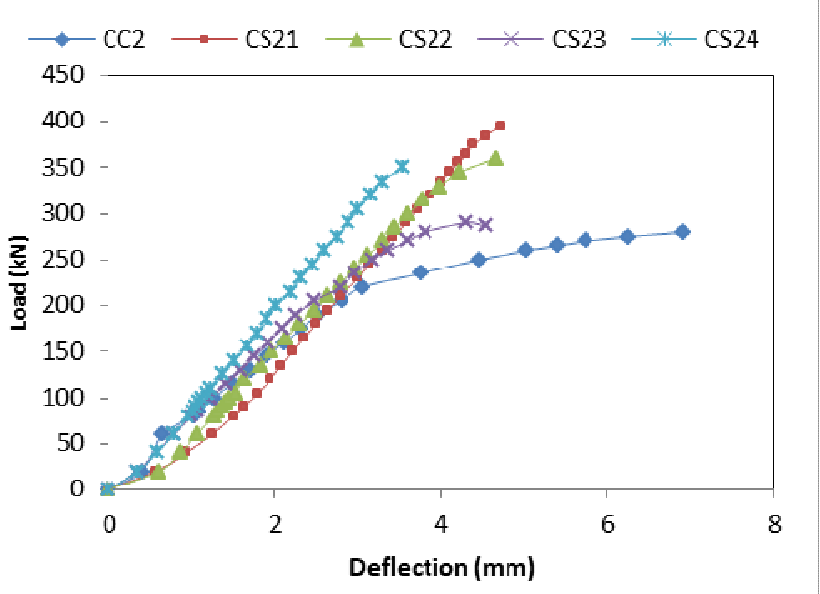

(b) effective depth/ $\operatorname{span}=1.25$

Fig. 5 Effect of strength configuration on response

Also, Figure depicted that the lowest recorded value of crack width is about $0.31 \mathrm{~mm}$ and $0.21 \mathrm{~mm}$ for a/d of 0.85 and 1.25 respectively when adopting upside down $\mathrm{V}$-shaped configuration (strengthening steel bar in tension). The effect of the method of strengthening on crack width development for the two groups of specimens is shown in Fig. 8. It can be seen clearly that the best strengthening configuration in term of crack width development is that when the NSM steel bars be in tension (CS14 and CS42 corbels). 


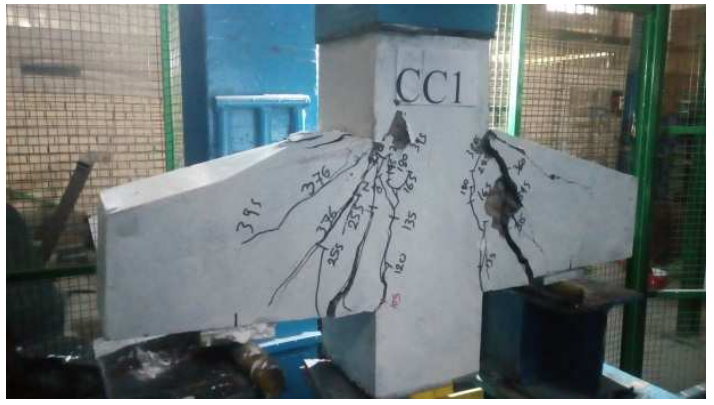

(a) Specimen CC1

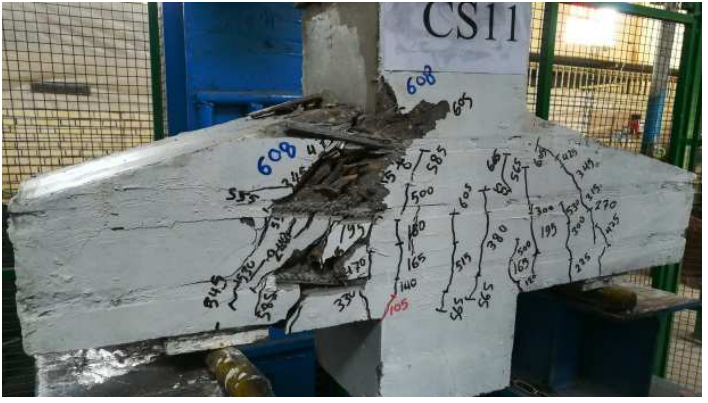

(c) Specimen CS11

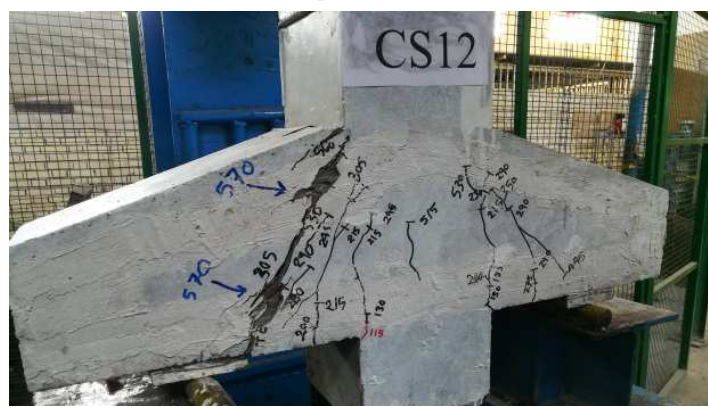

(e) Specimen CS12

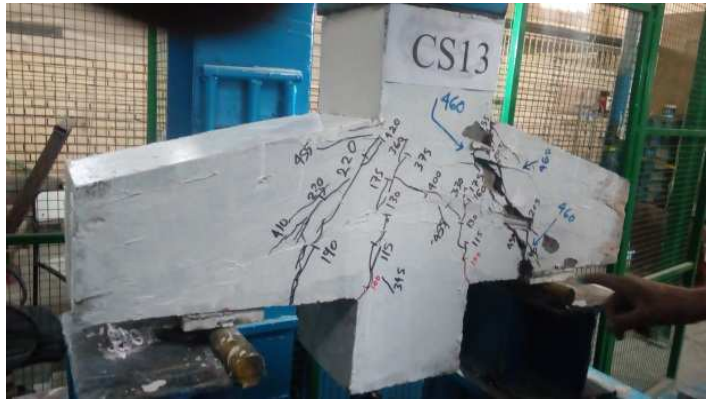

(g) Specimen CS13

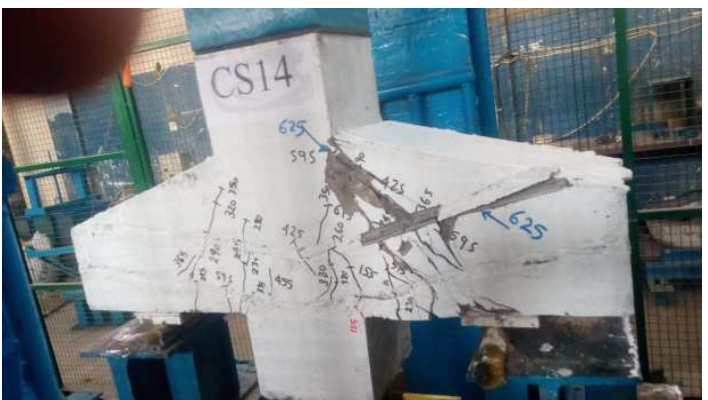

(i) Specimen CS14

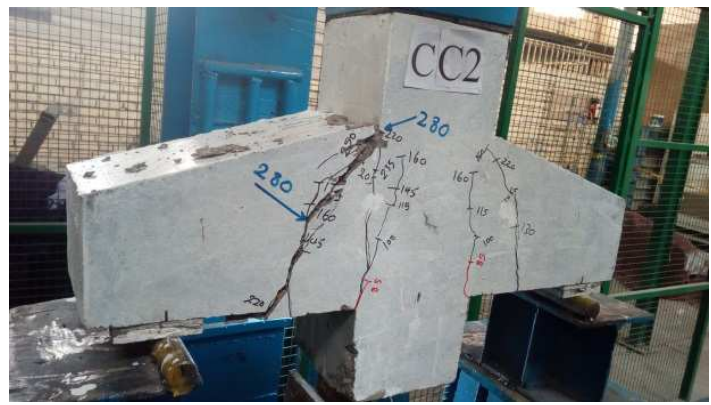

(b) Specimen CC2

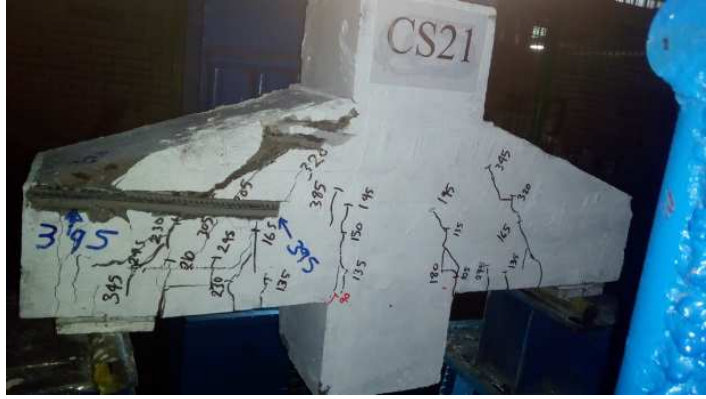

(d) Specimen CS21

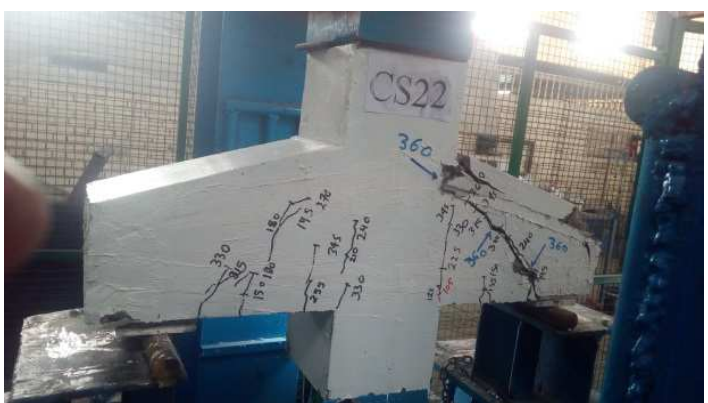

(f) Specimen CS22

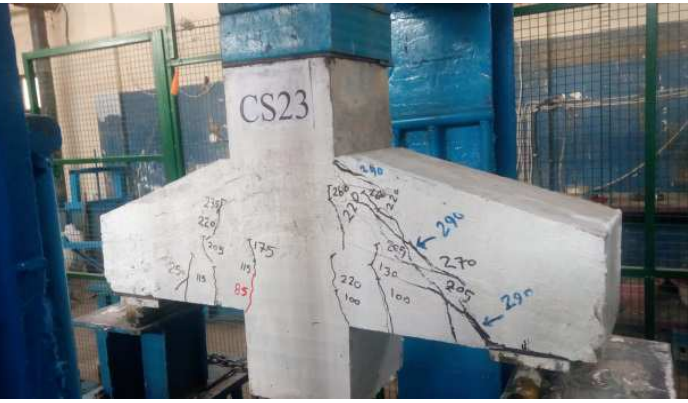

(h) Specimen CS23

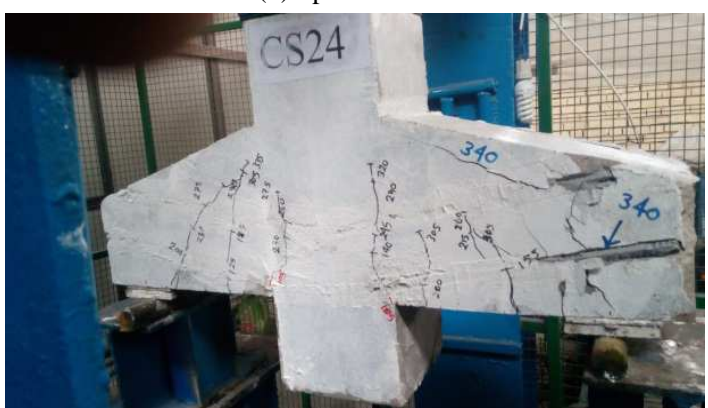

(j) Specimen CS24

Fig. 6 Crack patterns at failure of tested corbels 
TABLE III

CRACKING AND ULTIMATE LOADS AND MODE OF FAILURE

\begin{tabular}{|c|c|c|c|c|c|c|c|c|c|c|}
\hline Group & \multicolumn{5}{|c|}{$\mathrm{A}(\mathbf{a} / \mathbf{d}=\mathbf{0 . 8 5})$} & \multicolumn{5}{|c|}{$B(a / d=1.25)$} \\
\hline designation & CC1 & CS11 & CS12 & CS13 & CS14 & $\mathrm{CC2}$ & CS21 & CS22 & CS23 & CS24 \\
\hline Cracking load $(k N)$ & 105 & 105 & 115 & 100 & 125 & 85 & 90 & 105 & 85 & 105 \\
\hline Ultimate Load (kN) & $399^{*}$ & 608 & 570 & 460 & 625 & $280^{* * *}$ & 395 & 360 & 286 & 350 \\
\hline$\% \mathbf{P}_{0}$ & - & 52 & 43 & 15 & 57 & - & 41 & 29 & 2 & 25 \\
\hline 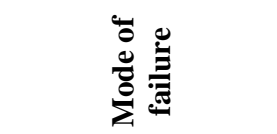 & 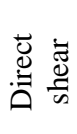 & 哭 & 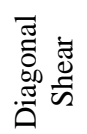 & 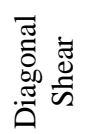 & D゙્ & 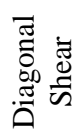 & Dृ̃ & D己 & 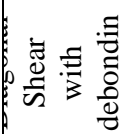 & 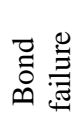 \\
\hline
\end{tabular}
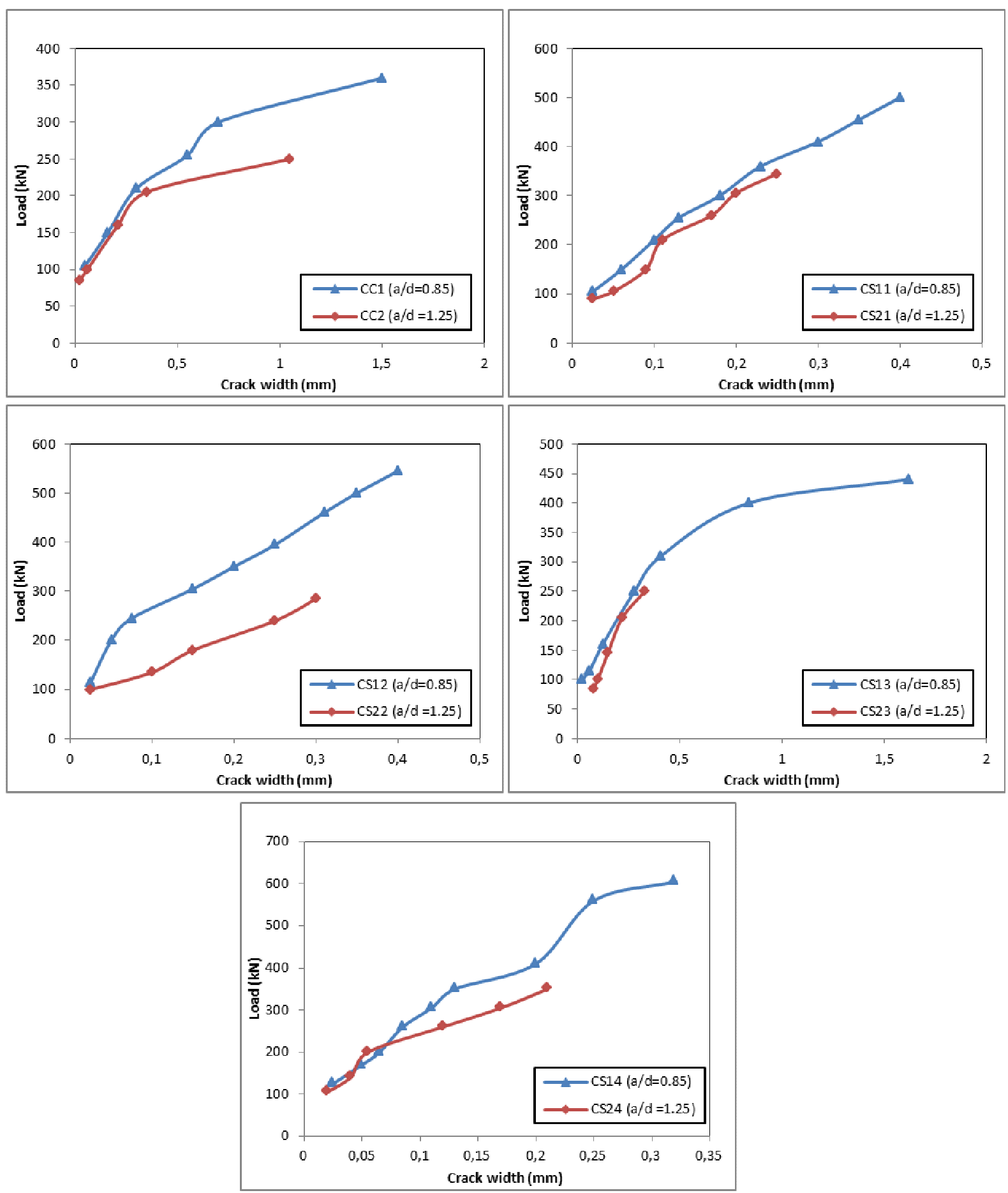

Fig. 7 Crack width development for tested corbels 


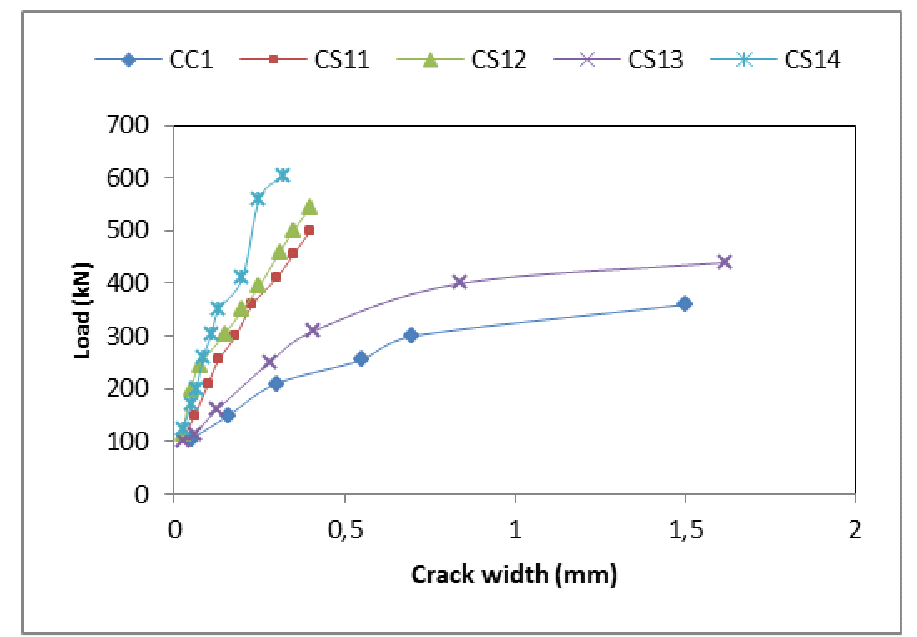

(a) effective depth/ span $=0.85$

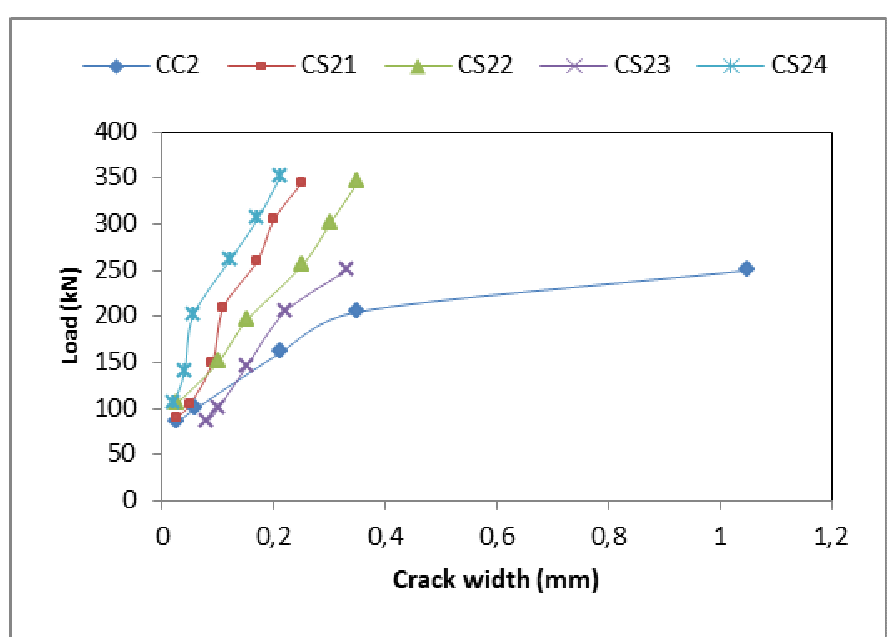

(b) effective depth/ span $=1.25$

Fig. 8 Effect of strength configuration on development of crack width

\section{CONCLUSIONS}

Shear span/ depth ratio (a/d) has a noticeable effect on RC corbels. Changing a/d from 1.25 to 0.85 results in a reduction in the crack and ultimate loads of $20 \%$ and $30 \%$ respectively. This effect is reduced when specimens are strengthened with NSM steel bar system, i.e., the effect of a/d is ranged by (9-16) \% and (23-38)\% respectively. The NSM steel bar system yielded a significant improvement in the ultimate load capacity of $57 \%$ and $41 \%$ for a/d of 0.85 and 1.25 respectively. Also, the results reveal that the "Upside down V-shaped" scheme is more efficient for small $\mathrm{a} / \mathrm{d}$ values $(\mathrm{a} / \mathrm{d}<1)$. Whereas, the configuration of installing horizontal bars is more convenient for large a/d values $(\mathrm{a} / \mathrm{d}>1)$.

A gradual transition from direct shear to diagonal shear for unstrengthened specimens when adopting higher values of a/d. For strengthened specimens with a/d of 0.85 different failure modes can be seen depending on the configuration of strengthening. With a/d of 1.25 , it is found that the general mode of failure, to be a bond failure. For unstrengthened specimens, a localization and smaller number of cracks near the column was recognized compared with the higher intensity of spread cracks for strengthened specimens.

Higher a/d value results in higher rate of crack widening for a specific load. Also, it is found that the best strengthening configuration in term of crack width development is that when the NSM steel bars be in tension (Upside down V-shaped). The ductility decreased with increasing a/d value (from 0.85-1.25). Also, the results revealed the strengthening leads to some elimination of ductility in value depending on the strengthening scheme.

\section{REFERENCES}

[1] L. A. G. Yassin and Q. A. M. Hasan, "Reinforced Concrete CorbelsState of the Art.," J. Mater. Eng. Struct. «JMES», vol. 2, no. 4, pp. 180-205, 2016.
[2] D. L. Araújo, S. A. Azevedo, E. D. Muniz, E. M. O. Silva, and L. A. Oliveira Júnior, "Strength evaluation of concrete corbels cast in a different stage from the column," Rev. Ibracon Estruturas e Mater., vol. 10, no. 2, pp. 509-546, 2017.

[3] A. H. Mattock, K. C. Chen, and K. Soongswang, "The behavior of reinforced concrete corbels," PCI J., vol. 21, no. 2, pp. 52-77, 1976.

[4] O. Q. Aziz, "Shear strength behavior of crushed stone reinforced concrete corbels," in 26th Conference on our World in Concrete \& Structures, pp. 27-28.

[5] G. Campione, L. Mendola L, and M. Papia, "Strength and ductility of fiber reinforced concrete corbels subjected to vertical loads," in Sixth Rilem Symposium on Fibre Reinforced Concrete (FRC), BEFIB, 2004, pp. 1113-1122.

[6] A. M. A. Hafez, M. M. Ahmed, H. Diab, and A. A. M. Drar, "Shear behavior of high strength fiber reinforced concrete corbels," J. Eng. Sci., vol. 40, pp. 969-987, 2012.

[7] I. A. Al-Shaarbaf, A. A. Al-Azzawi, and R. S. Farahan, "Experimental Investigation on the Behavior of Reinforced Concrete Corbels under Repeated Loadings," J. Eng. Sustain. Dev., vol. 19, no. 4, pp. 126-147, 2015.

[8] D. A. P. Sayed Shoeb Iliyas and D. N. Kakade, "The Behavior of Reinforced Concrete Corbels with Steel Fibers and Shear Strength Prediction."

[9] J. M. Yang, K. H. Min, H. O. Shin, and Y. S. Yoon, "The use of Theaded bars in high-strength concrete members," Fract. Mech. Concr. Concr. Struct. High Performance, Fiber Reinf. Concr. Spec. Loadings Struct. Appl., pp. 1328-1335, 2010.

[10] S. Ahmad, A. Elahi, S. Kundi, and W. Haq, "Investigation of shear behavior of corbel beams strengthened with CFRP," Life Sci. J., vol. 10, no. 12 SPL.ISS., pp. 961-965, 2013.

[11] A. A. Mohammed and D. K. Assi, "Behavior of reinforced concrete corbels strengthened with ferrocement sheets," GAU J. Soc. App. Sci., vol. 6, no. 10, pp. 93-102, 2014.

[12] I. Ivanova and J. Assih, "Experimental Study of Local Behavior of Strengthened Reinforced Concrete Short Corbel by Bonding Carbon Fiber Fabrics,” Int. J. Struct. Civ. Engg. Res, vol. 4, no. 1, 2015.

[13] J. Assih, I. Ivanova, D. Dontchev, and A. Li, "Concrete damaged analysis in strengthened corbel by external bonded carbon fibre fabrics," Appl. Adhes. Sci., vol. 3, no. 1, p. 21, 2015.

[14] Z. Yujie, "FRP strengthening of non-flexural reinforced concrete members based on strut-and-tie modelling." National University of Singapore (Singapore), 2016.

[15] T. Urban and Ł. Krawczyk, "Strengthening corbels using post installed threaded rods," Struct. Concr., vol. 18, no. 2, pp. 303-315, 2017. 